\title{
An analysis of the effect of changes in growth temperature on proteolysis in vivo in the psychrophilic bacterium Vibrio sp. strain ANT-300
}

\author{
TADASHI ARAKI \\ Institute of Low Temperature Science, Hokkaido University, Sapporo 060, Japan
}

(Received 27 March 1992; revised 25 May 1992; accepted 18 June 1992)

\begin{abstract}
In the psychrophilic bacterium Vibrio sp. strain ANT-300, the rate of protein degradation in vivo, measured at fixed temperatures, increased with elevation of the growth temperature. A shift in growth temperature induced a marked increase in this rate. Dialysed cell-free extracts hydrolysed exogenous insulin, globin and casein (in decreasing order of activity) but did not hydrolyse exogenous cytochrome $c$. Cells contained at least seven proteases separated by DEAE-Sephacel chromatography, one of which was an ATP-dependent serine protease. The ATP-dependent proteolytic activity in extracts of cells incubated for $3 \mathrm{~h}$ at $16^{\circ} \mathrm{C}$ after a shift-up from $0{ }^{\circ} \mathrm{C}$ increased to a level $36 \%$ and $17 \%$ higher than that of cells grown at $0{ }^{\circ} \mathrm{C}$ and $13{ }^{\circ} \mathrm{C}$, respectively. $\mathrm{A}$ shift-down to $0{ }^{\circ} \mathrm{C}$ from $13{ }^{\circ} \mathrm{C}$ induced only a slight increase in the proteolytic activity. Extracts of all cells, whether exposed to temperature shifts or not, showed the same temperature dependence with respect to both ATP-dependent and ATP-independent protease activity. In all the extracts these proteases also exhibited the same heat lability. The ATP-dependent protease was inactivated by incubation at temperatures above $25{ }^{\circ} \mathrm{C}$. There was an increase in ATP-independent protease activity during incubation at temperatures between 25 and $30{ }^{\circ} \mathrm{C}$, but a decrease at $35^{\circ} \mathrm{C}$ and higher. These results suggest that the marked increases in proteolysis in vivo, caused by a shift in temperature, may result not only from increases in levels of ATP-dependent serine protease(s) but also from increases in the susceptibility of proteins to degradation.
\end{abstract}

\section{Introduction}

The rate of protein turnover in exponentially growing Escherichia coli is usually low, and the degradation of intracellular proteins is selective and responsive to the nutritional state of the cells (Pine, 1972; St John \& Goldberg, 1978). Thus, it appears that the degradation of proteins is metabolically regulated. While most proteins in $E$. coli are stable (Larrabee et al., 1980; Mosteller et al., 1980), a number of proteins, such as SulA, RcsA and $\sigma^{32}$, are degraded rapidly by energy-dependent proteases (Gottesman, 1987). In micro-organisms that live in extreme environments, such as thermophiles, psychrotrophs and halophiles, the rates of degradation of proteins are much higher than in mesophiles (Amelunxen \& Murdoch, 1983; Hipkiss et al., 1980; Potier et al., 1985). However, very little information is available about the stability of cellular proteins and the properties of the enzymes that are

Abbreviations: $\left[{ }^{14} \mathrm{C}-\mathrm{Me}\right],{ }^{14} \mathrm{C}$-methylated; PMSF, phenylmethylsulphonyl fluoride; HMPS, p-hydroxymercuryphenyl sulphonic acid; BSA, bovine serum albumin; TCA, trichloroacetic acid. involved in the turnover of proteins in such microorganisms.

Potier et al. $(1987 a, b, 1990)$ reported that the proteolytic activity in extracts of the psychrotrophic Arthrobacter sp. strain $\mathrm{S}_{1} 55$ grown at $10^{\circ} \mathrm{C}$ was significantly more heat-labile than that in extracts of cells grown at $20^{\circ} \mathrm{C}$ and $32^{\circ} \mathrm{C}$. I recently showed that the levels of individual proteins in the psychrophilic Vibrio sp. strain ANT-300 changed in response to the growth temperature (Araki, 1991 $a, b$ ). Moreover, temperature shifts caused transient changes in the levels of a number of proteins. The results suggested that the levels of individual proteins may be regulated by degradation as well as by synthesis. The studies described here were undertaken to clarify whether, during the response of cells to changes in temperature, changes in rates of degradation of proteins in vivo are closely correlated with levels of proteases or of substrates that are susceptible to degradation.

\section{Methods}

Bacterial strain and growth conditions. The psychrophilic Vibrio sp. strain ANT-300 was grown in an artificial seawater medium, 
supplemented with nutrients, as previously described (Araki, 1991a). Cells were grown to the mid-exponential phase at either $0^{\circ} \mathrm{C}$ or $13^{\circ} \mathrm{C}$. In the experiments that involved temperature shifts, portions of each culture were mixed with two volumes of fresh medium, which had been pre-equilibrated to the desired temperature, and held at this temperature for the periods indicated.

Preparation of cell-free extracts. Cells were harvested by centrifugation at $10000 \mathrm{~g}$ for $10 \mathrm{~min}$ at the growth temperature, washed with artificial seawater and then resuspended in $50 \mathrm{mM}$-Tris/ $\mathrm{HCl}$ buffer $(\mathrm{pH}$ 7.8) containing $10 \mathrm{~mm}-\mathrm{MgCl}_{2}, 2 \mathrm{mM}-\mathrm{EDTA}, 2 \mathrm{~mm}-\mathrm{NaN}_{3}, 50 \mathrm{~mm}-$ mercaptoethanol and $10 \%(\mathrm{v} / \mathrm{v})$ glycerol, to give a final cell concentration of $250 \mathrm{mg}$ wet weight $\mathrm{ml}^{-1}$. Each suspension of cells was gently sonicated with an Artek sonic dismembrator for $2 \times 60 \mathrm{~s}$ at $0^{\circ} \mathrm{C}$. After centrifugation at $20000 \mathrm{~g}$ for $30 \mathrm{~min}$, the supernatant was dialysed for $20 \mathrm{~h}$ at $4{ }^{\circ} \mathrm{C}$ against $10 \mathrm{mM}$-Tris/ $\mathrm{HCl}$ buffer (pH 7.8) containing $5 \mathrm{mM}-\mathrm{MgCl}_{2}, 1 \mathrm{~mm}$-EDTA, $1 \mathrm{~mm}-\mathrm{NaN}_{3}, 50 \mathrm{~mm}$-mercaptoethanol and $10 \%(\mathrm{v} / \mathrm{v})$ glycerol (buffer $\mathrm{A})$, and the insoluble material was removed by centrifugation. The concentration of protein in these preparations ranged between 50 and $60 \mathrm{mg} \mathrm{ml}^{-1}$.

Fractionation of cell-free extracts on DEAE-Sephacel. Dialysed cellfree extracts ( $1 \mathrm{~g}$ protein) were applied to a DEAE-Sephacel column $(1.5 \times 15 \mathrm{~cm})$ equilibrated with buffer $A$. The column was washed with two column volumes of the same buffer. Bound proteins were then eluted with a linear gradient of $\mathrm{KCl}$ from 0 to $0.4 \mathrm{M}$ in a total volume of $300 \mathrm{ml}$. The flow rate was $20 \mathrm{ml} \mathrm{h}^{-1}$, and fractions of 100 drops (about $3.5 \mathrm{ml}$ ) were collected. Absorbance at $280 \mathrm{~nm}$ was used to monitor eluted material.

Preparation of radiolabelled substrates. Bovine globin and insulin (Sigma) were methylated with $\left[{ }^{14} \mathrm{C}\right]$ formaldehyde (New England Nuclear) and sodium cyanoborohydride by the method of DottavioMartin \& Ravel (1978). The specific activities of $\left[{ }^{14} \mathrm{C}-\mathrm{Me}\right]$ globin and $\left[{ }^{14} \mathrm{C}-\mathrm{Me}\right]$ insulin were 0.10 and $0.33 \mathrm{MBq}(\mathrm{mg} \text { protein })^{-1}$, respectively. $\left[{ }^{14} \mathrm{C}-\mathrm{Me}\right]$ Casein $\left(89 \mathrm{kBq} \mathrm{mg}^{-1}\right)$ and $\left[{ }^{14} \mathrm{C}-\mathrm{Me}\right]$ cytochrome $c(1 \mathrm{MBq}$ $\mathrm{mg}^{-1}$ ) were obtained from New England Nuclear.

Determination of rates of degradation of proteins in vivo. Cells grown to the mid-exponential phase at either $0{ }^{\circ} \mathrm{C}$ or $13^{\circ} \mathrm{C}$ were separately transferred to the temperatures indicated and then incubated for $30 \mathrm{~min}$ at that temperature. The cells were then labelled with $\mathrm{L}-[\mathrm{U}-$ ${ }^{14}$ Clleucine $\left(12.9 \mathrm{GBq} \mathrm{mmol}{ }^{-1}\right.$, Amersham) at $148 \mathrm{kBq} \mathrm{ml}^{-1}$ for $30 \mathrm{~min}$ at the temperature indicated. They were collected by centrifugation at $10000 \mathrm{~g}$ for $10 \mathrm{~min}$, and resuspended in artificial seawater medium containing $1 \mathrm{mg}$ non-radioactive leucine $\mathrm{ml}^{-1}$ and $400 \mu \mathrm{g}$ chloramphenicol ml-1. Portions $(5 \mathrm{ml})$ of each cell suspension were separately incubated at 0,13 and $21^{\circ} \mathrm{C}$, and $0.5 \mathrm{ml}$ aliquots were removed at appropriate intervals and mixed with $2 \mathrm{ml}$ cold $10 \%(\mathrm{w} / \mathrm{v})$ TCA. The precipitation of proteins was initiated by addition of $10 \mu \mathrm{l}$ of $5 \%(w / v)$ BSA as a carrier to each tube. After centrifugation at $3000 \mathrm{~g}$ for $15 \mathrm{~min}$, aliquots $(0.5 \mathrm{ml})$ of the supernatant were monitored for radioactivity in the presence of $4.5 \mathrm{ml} \mathrm{Aquasol-2}$ (New England Nuclear) in a liquid scintillation counter. The extent of protein degradation was estimated from the radioactivity liberated from cellular proteins into the TCA-soluble fraction and the parameter 'percentage proteolysis' was defined as the amount of radioactivity liberated expressed as a percentage of that present initially in cells.

Assay of proteolytic activity in vitro. The reaction mixture contained $50 \mathrm{~mm}$-Tris/HCl buffer ( $\mathrm{pH} \mathrm{8.0)}, 10 \mathrm{~mm}-\mathrm{MgCl}_{2}, 100 \mu \mathrm{g}$ of radiolabelled proteins, with ATP and inhibitors added as indicated, in a final volume of $1.0 \mathrm{ml}$. The reaction was initiated by the addition of either cell extract ( $3 \mathrm{mg}$ protein) or enzyme fraction $(200 \mu \mathrm{l})$. Samples $(100 \mu \mathrm{l})$ were removed at appropriate intervals and mixed with $10 \mu \mathrm{l} 5 \%(\mathrm{w} / \mathrm{v})$ BSA and $390 \mu \mathrm{l}$ of $10 \%(\mathrm{w} / \mathrm{v})$ TCA. After $30 \mathrm{~min}$ the samples were centrifuged at $3000 \mathrm{~g}$ for $15 \mathrm{~min}$, and then the radioactivity in TCAsoluble fractions was determined as described above.

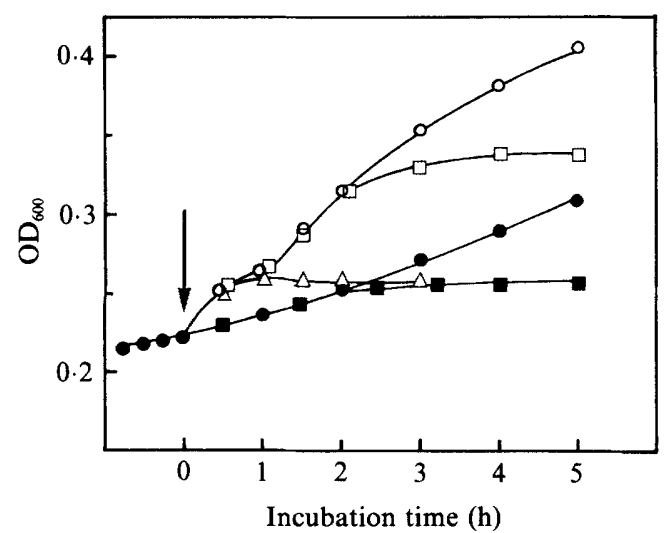

Fig. 1. Effects of temperature shifts and antibiotics on growth of Vibrio sp. strain ANT-300. Portions of a culture incubated at $0{ }^{\circ} \mathrm{C}$ were transferred to $16^{\circ} \mathrm{C}$ at zero time (arrow), and incubated with no addition $(O)$, with rifamicin $\left(100 \mu \mathrm{g} \mathrm{ml}^{-1}\right)(\triangle)$, or with chloramphenicol $\left(400 \mu \mathrm{g} \mathrm{ml}^{-1}\right)(\square)$. Other portions of the culture were maintained at $0{ }^{\circ} \mathrm{C}$ with no addition (๑) or with chloramphenicol $\left(400 \mu \mathrm{g} \mathrm{ml}^{-1}\right)(\mathbb{a})$.

\section{Results}

\section{Effects of temperature shifts and antibiotics on growth}

The psychrophilic Vibrio sp. strain ANT-300 grows exponentially at temperatures below $13{ }^{\circ} \mathrm{C}$ but cannot grow at temperatures above $18{ }^{\circ} \mathrm{C}$. A shift-up from $0{ }^{\circ} \mathrm{C}$ to $16^{\circ} \mathrm{C}$ resulted in an increased rate of growth (Fig. 1). An initial stimulation of growth was followed by a more gradual increase in growth rate. At $16^{\circ} \mathrm{C}$, Vibrio sp. strain ANT-300 showed apparently exponential growth during the first few hours, and numbers of filamentous cells increased progressively with time (data not shown). After a shift-up in the presence of antibiotics, chloramphenicol markedly inhibited growth after $2 \mathrm{~h}$, and rifampicin completely inhibited growth after $45 \mathrm{~min}$ (Fig. 1). Chloramphenicol also inhibited the growth of cells incubated at $0{ }^{\circ} \mathrm{C}$, with a similar time-course to that at $16{ }^{\circ} \mathrm{C}$.

\section{Degradation of cellular proteins after temperature shifts}

When cells grown at $0{ }^{\circ} \mathrm{C}$ were labelled for 30 min with $\left[{ }^{14} \mathrm{C}\right]$ leucine at $0{ }^{\circ} \mathrm{C}$ and at $16{ }^{\circ} \mathrm{C}$ the radioactivity in TCA-soluble fractions was about $45 \%$ and $25 \%$, respectively, of the total $\left[{ }^{14} \mathrm{C}\right]$ leucine incorporated into cells (Fig. $2 a, b$ ). During a subsequent chase, the radioactivity in TCA-soluble fractions of cells labelled at $0^{\circ} \mathrm{C}$ decreased during the first $2 \mathrm{~h}$ at $0^{\circ} \mathrm{C}$ and $45 \mathrm{~min}$ at $16^{\circ} \mathrm{C}$ and then increased progressively with time. Even a high concentration of unlabelled leucine and chloramphenicol failed to prevent the reincorporation of $\left[{ }^{14} \mathrm{C}\right]$ leucine into cellular proteins in cells labelled and chased at low temperatures. Cells labelled at $16^{\circ} \mathrm{C}$ showed no decrease 


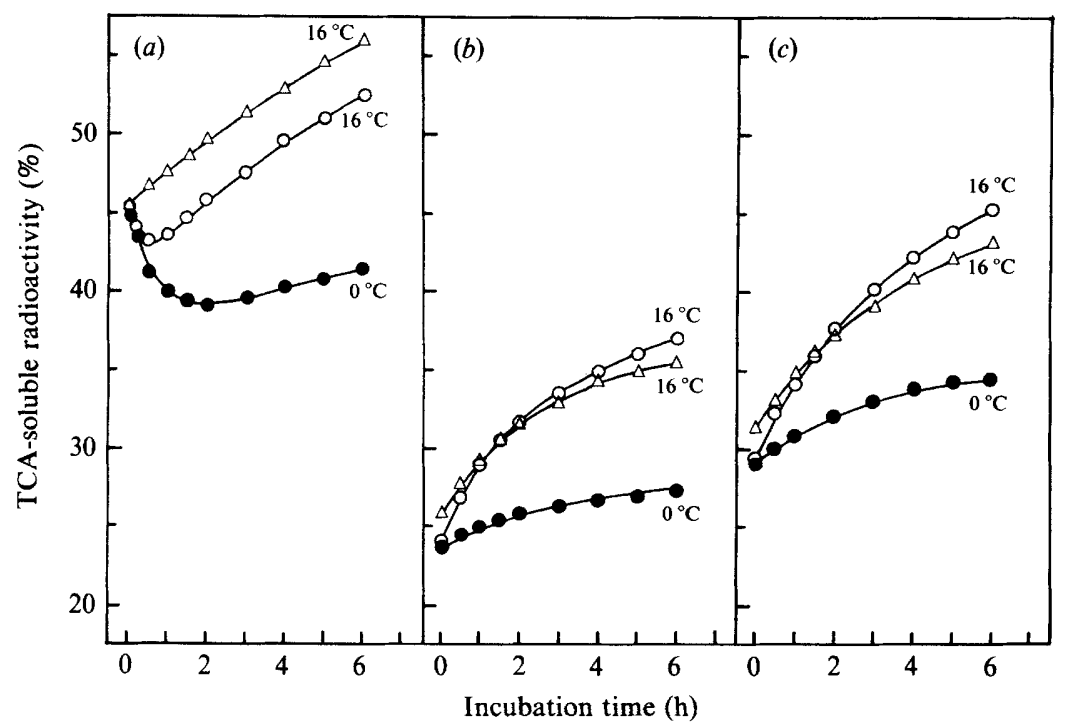

Fig. 2. Changes in TCA-soluble radioactivity liberated from ${ }^{14} \mathrm{C}$-labelled cellular proteins during a chase. Cells grown at $0{ }^{\circ} \mathrm{C}$ were labelled with $\left[{ }^{14} \mathrm{C}\right]$ leucine in the absence $(O, \bullet)$ or in the presence of rifampicin $\left(100 \mu \mathrm{g} \mathrm{ml}^{-1}\right)(\triangle)$ for $30 \mathrm{~min}$ at $0^{\circ} \mathrm{C}(a)$, for $30 \mathrm{~min}$ at $16^{\circ} \mathrm{C}(b)$, and for $30 \mathrm{~min}$ at $16^{\circ} \mathrm{C}$ after incubation for $2.5 \mathrm{~h}$ at $16^{\circ} \mathrm{C}(\mathrm{c})$, and then chased at $0{ }^{\circ} \mathrm{C}(\bullet)$ or $16^{\circ} \mathrm{C}$ $(\mathrm{O}, \Delta)$ in the presence of chloramphenicol $(400 \mu \mathrm{g}$ $\mathrm{ml}^{-1}$ ). Each point represents the mean of duplicate assays in one of four separate experiments. All the experiments showed similar patterns; individual results were within $15 \%$ of one another.

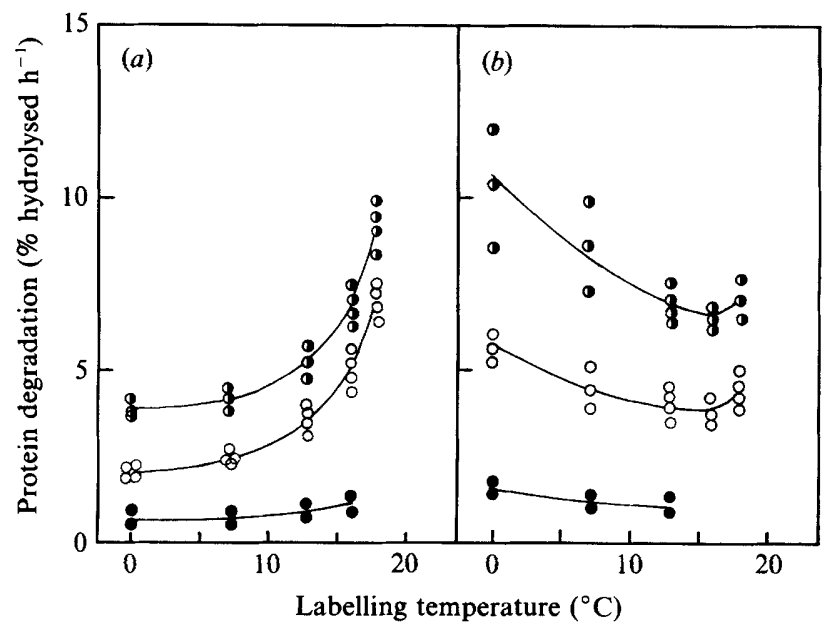

Fig. 3. Effects of temperature shifts on the rate of protein degradation in Vibrio sp. strain ANT-300. Cells grown at $0{ }^{\circ} \mathrm{C}(a)$ or at $13^{\circ} \mathrm{C}(b)$ were incubated for $30 \mathrm{~min}$ at the temperatures indicated, labelled with $\left[{ }^{14} \mathrm{C}\right]$ leucine for $30 \mathrm{~min}$ at that temperature, and then chased in the presence of chloramphenicol $\left(400 \mu \mathrm{g} \mathrm{ml}^{-1}\right)$ at $0^{\circ} \mathrm{C}(\bullet), 13^{\circ} \mathrm{C}(0)$, and $21^{\circ} \mathrm{C}(\mathbf{O})$. The rates of protein degradation are expressed as the percentage of the total radioactivity present initially in the cells that was liberated in $60 \mathrm{~min}$.

in the TCA-soluble radioactivity during the chase at either $0{ }^{\circ} \mathrm{C}$ or $16^{\circ} \mathrm{C}$, and the rate of increase in TCAsoluble radioactivity was slightly greater than that in cells labelled at $0{ }^{\circ} \mathrm{C}$. During the chase at $16^{\circ} \mathrm{C}$, the rate of degradation of proteins in cells labelled at $16^{\circ} \mathrm{C}$ was less if the cells had been labelled in the presence of rifampicin. However, the rate was still greater than that in cells labelled at $0^{\circ} \mathrm{C}$.

When cells that had been shifted to $16^{\circ} \mathrm{C}$ for $2.5 \mathrm{~h}$ were labelled with $\left[{ }^{14} \mathrm{C}\right]$ leucine at $16^{\circ} \mathrm{C}$ for $30 \mathrm{~min}$, the radioactivity in TCA-soluble fractions was about $30 \%$ of the total radioactivity (Fig. $2 c$ ). The rate of degradation of proteins in these cells at either $0{ }^{\circ} \mathrm{C}$ or $16^{\circ} \mathrm{C}$ was apparently increased over that in cells labelled immediately after the shift-up. The rate of degradation of proteins in cells labelled in the absence of rifampicin was slightly greater than that in cells labelled in the presence of rifampicin.

In order to clarify the effect of a temperature shift on the degradation of proteins, cells grown at either $0{ }^{\circ} \mathrm{C}$ or $13^{\circ} \mathrm{C}$ were incubated for $30 \mathrm{~min}$ at various temperatures, labelled with [ $\left.{ }^{14} \mathrm{C}\right] l$ leucine for $30 \mathrm{~min}$, and the subsequent rates of protein degradation at 0,13 , or $21^{\circ} \mathrm{C}$ were examined. The rate of protein degradation in cells grown at $0{ }^{\circ} \mathrm{C}$ clearly increased as the labelling temperature increased (Fig. $3 a$ ). In contrast, the rate of protein degradation in cells grown at $13{ }^{\circ} \mathrm{C}$ increased if the cells were labelled at temperatures either lower or higher than $13^{\circ} \mathrm{C}$ (Fig. $3 b$ ). When the cells were labelled at temperatures higher than $13^{\circ} \mathrm{C}$, the increase in the rate of protein degradation in cells grown at $13{ }^{\circ} \mathrm{C}$ was lower than that in cells grown at $0^{\circ} \mathrm{C}$.

\section{Proteolytic activity of cell-free extracts}

The degradation of radiolabelled proteins by dialysed cell-free extracts was examined in the presence and absence of $3 \mathrm{~mm}$-ATP (Table 1). Extracts from cells grown at $0{ }^{\circ} \mathrm{C}$ and $13{ }^{\circ} \mathrm{C}$ hydrolysed $\left[{ }^{14} \mathrm{C}\right.$-Me $]$ casein, $\left[{ }^{14} \mathrm{C}\right.$-Me]globin and $\left[{ }^{14} \mathrm{C}\right.$-Me]insulin to TCA-soluble material, but they had hardly any effect on $\left[{ }^{14} \mathrm{C}\right.$ Me]cytochrome $c$, from which no TCA-soluble radioactivity could be detected after incubation at $30^{\circ} \mathrm{C}$ for $3 \mathrm{~h}$.

The proteolytic activity of the extracts was dependent on the protein substrate. The extracts of cells grown at either $0^{\circ} \mathrm{C}$ or $13^{\circ} \mathrm{C}$ degraded insulin extensively in the absence of ATP, whereas their ability to hydrolyse insulin was somewhat reduced by the addition of ATP. 
Table 1. Effects of ATP on the degradation of various proteins by extracts of cells grown at $0^{\circ} \mathrm{C}$ and at $13{ }^{\circ} \mathrm{C}$

\begin{tabular}{|c|c|c|c|c|}
\hline \multirow{2}{*}{$\begin{array}{l}\text { Growth } \\
\text { temp. }\end{array}$} & \multirow[b]{2}{*}{ Substrate } & \multicolumn{2}{|c|}{$\begin{array}{c}\text { Proteolytic activity } \\
{\left[\% \text { hydrolysed } \mathrm{h}^{-1}(\mathrm{mg} \text { protein })^{-1}\right]}\end{array}$} & \multirow{2}{*}{$\begin{array}{c}\text { Activity with ATP } \\
\text { ( } \% \text { of activity } \\
\text { with no ATP) }\end{array}$} \\
\hline & & Without ATP & With ATP & \\
\hline $0^{\circ} \mathrm{C}$ & $\begin{array}{l}\text { Casein } \\
\text { Globin } \\
\text { Insulin } \\
\text { Cytochrome } c\end{array}$ & $\begin{array}{c}1 \cdot 7 \pm 0 \cdot 1 \\
3 \cdot 5 \pm 0 \cdot 3 \\
33 \cdot 9 \pm 2 \cdot 1 \\
<0 \cdot 01\end{array}$ & $\begin{array}{c}7.4 \pm 0.6 \\
7.6 \pm 0.6 \\
30 \cdot 2 \pm 1.6 \\
<0.01\end{array}$ & $\begin{array}{r}435 \pm 37 \\
217 \pm 24 \\
89 \pm 5 \\
\pm\end{array}$ \\
\hline $13^{\circ} \mathrm{C}$ & $\begin{array}{l}\text { Casein } \\
\text { Globin } \\
\text { Insulin } \\
\text { Cytochrome } c\end{array}$ & $\begin{array}{r}1.6 \pm 0.1 \\
3 \cdot 5 \pm 0.2 \\
35 \cdot 5 \pm 2.0 \\
<0.01\end{array}$ & $\begin{array}{c}8.1 \pm 0.5 \\
8.2 \pm 0.6 \\
31 \cdot 6 \pm 1 \cdot 5 \\
<0.01\end{array}$ & $\begin{array}{r}506 \pm 44 \\
234 \pm 25 \\
89 \pm 5 \\
-\end{array}$ \\
\hline
\end{tabular}

Table 2. Effects of temperature shifts on the proteolytic activity in cells of Vibrio sp. strain ANT-300

Dialysed cell-free extracts were prepared from cells either maintained at a constant temperature or exposed to temperature shifts. Degradation of $\left[{ }^{14} \mathrm{C}\right.$ Me]casein by cell-free extracts was assayed at $30^{\circ} \mathrm{C}$ in the absence or presence of 3 mM-ATP. The proteolytic activities are expressed as the amount of TCAsoluble radioactivity released. The values given are means of five independent experiments $( \pm S D)$

\begin{tabular}{|c|c|c|c|c|}
\hline \multirow{2}{*}{$\begin{array}{l}\text { Growth } \\
\text { temp. }\end{array}$} & \multirow{2}{*}{$\begin{array}{c}\text { Temp. } \\
\text { shift }\end{array}$} & \multicolumn{2}{|c|}{$\begin{array}{c}\text { Proteolytic activity } \\
{\left[\text { d.p.m. } \mathrm{h}^{-1}(\text { mg protein })^{-1}\right]}\end{array}$} & \multirow{2}{*}{$\begin{array}{l}\text { Activity with ATP } \\
\text { (\% of activity } \\
\text { with no ATP) }\end{array}$} \\
\hline & & Without ATP & With ATP & \\
\hline $0^{\circ} \mathrm{C}$ & $\begin{array}{l}\text { None } \\
16^{\circ} \mathrm{C}, 3 \mathrm{~h}\end{array}$ & $\begin{array}{l}909 \pm 54 \\
879 \pm 61\end{array}$ & $\begin{array}{l}3956 \pm 328 \\
5212 \pm 342\end{array}$ & $\begin{array}{l}435 \pm 37 \\
593 \pm 48\end{array}$ \\
\hline $13^{\circ} \mathrm{C}$ & $\begin{array}{l}\text { None } \\
0^{\circ} \mathrm{C}, 3 \mathrm{~h}\end{array}$ & $\begin{array}{l}855 \pm 57 \\
859 \pm 59\end{array}$ & $\begin{array}{l}4325 \pm 268 \\
4464 \pm 319\end{array}$ & $\begin{array}{l}506 \pm 44 \\
520 \pm 47\end{array}$ \\
\hline
\end{tabular}

In the absence of ATP, the rates of degradation of casein and globin were very low. The addition of ATP stimulated the degradation of these proteins by extracts of cells grown at either $0{ }^{\circ} \mathrm{C}$ or $13^{\circ} \mathrm{C}$. Maximal stimulation of proteolytic activity in both preparations was obtained at $3 \mathrm{mM}$-ATP (data not shown). In extracts of cells grown at $13^{\circ} \mathrm{C}$, the degree of stimulation by ATP was slightly higher than that in cells grown at $0{ }^{\circ} \mathrm{C}$.

To determine the effects of temperature shifts on proteolytic activity, extracts were prepared from cells grown at $0{ }^{\circ} \mathrm{C}$ and from parallel batches of cells incubated for $3 \mathrm{~h}$ after a shift-up to $16^{\circ} \mathrm{C}$. The ability to degrade $\left[{ }^{14} \mathrm{C}\right.$-Me $]$ casein was then measured. In the absence of ATP, both extracts degraded casein at almost the same rate. The proteolytic activity of both extracts was again markedly stimulated by the addition of ATP to $3 \mathrm{~mm}$ (Table 2): 4.4-fold and 5.9-fold stimulation for extracts from control and up-shifted cells, respectively.

Extracts were also prepared from cells grown at $13{ }^{\circ} \mathrm{C}$ and from cells incubated for $3 \mathrm{~h}$ after a shift-down from
$13{ }^{\circ} \mathrm{C}$ to $0{ }^{\circ} \mathrm{C}$. The proteolytic activity of both extracts was again markedly stimulated by the addition of ATP: $5 \cdot 1$-fold and 5.2-fold stimulation in extracts of control and down-shifted cells, respectively (Table 2). ATP had a much greater stimulatory effect upon the extracts of cells grown at $13{ }^{\circ} \mathrm{C}$ than upon those of cells grown at $0{ }^{\circ} \mathrm{C}$, presumably because there were higher levels of ATPdependent proteases. However, the change in the activity of ATP-dependent proteolysis after a shift-down was quite small.

Temperature dependence of proteolytic activity in the extracts

The effects of temperature on the degradation of $\left[{ }^{14} \mathrm{C}\right.$ $\mathrm{Me}]$ casein and $\left[{ }^{14} \mathrm{C}\right.$-Me]insulin were examined in dialysed cell-free extracts of cells grown at either $0{ }^{\circ} \mathrm{C}$ or $13^{\circ} \mathrm{C}$. In both types of extract, the rate of degradation of casein in the absence or presence of ATP displayed a similar temperature dependence (Fig. 4a). Similarly, in 


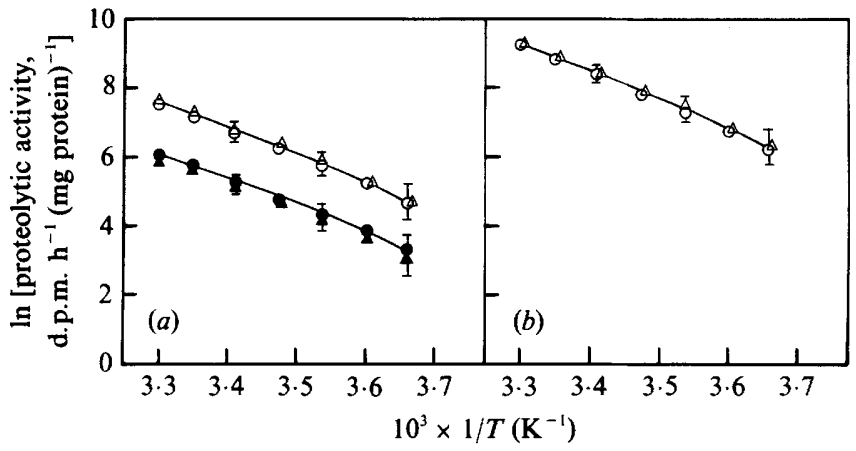

Fig. 4. Temperature dependence of the degradation of $\left[{ }^{14} \mathrm{C}-\mathrm{Me}\right]$ casein (a) and $\left[{ }^{14} \mathrm{C}-\mathrm{Me}\right]$ insulin $(b)$ by extracts of Vibrio sp. strain ANT-300. Dialysed cell-free extracts were prepared from cells grown at $0{ }^{\circ} \mathrm{C}$ (circles) and at $13^{\circ} \mathrm{C}$ (triangles). The degradation of proteins was assayed at the temperatures indicated in the absence $(\boldsymbol{\theta}, \mathbf{\Delta})$ or presence $(O, \Delta)$ of $3 \mathrm{~mm}$-ATP. The points and bars represent means from five experiments and ranges of results, respectively.

the case of insulin degradation, the activity in both extracts decreased in parallel with a reduction in the reaction temperature (Fig. $4 b$ ). No change in the temperature characteristics, as estimated from slopes of Arrhenius plots, was observed in extracts prepared from cells subjected to a temperature shift $\left(0^{\circ} \mathrm{C}\right.$ to $13^{\circ} \mathrm{C}$ or vice versa) (data not shown).

\section{Separation of proteolytic enzymes in cell-free extracts}

When a dialysed cell-free extract prepared from cells grown at $0{ }^{\circ} \mathrm{C}$ was passed through a DEAE-Sephacel column, seven different peaks of proteolytic activity against casein and insulin were found (Fig. 5). These were denoted peaks I-VII, according to their order of elution from the column. Enzymes of peak I did not adsorb to DEAE-Sephacel and showed high activity against casein and insulin in the absence of ATP. Enzymes in peak II showed casein-degrading activity in the absence of ATP and showed some insulin-degrading activity, which overlapped with enzymes of peak III that contained both insulin- and casein-degrading activities. Enzymes of peak IV showed high activity against insulin (Fig. $5 b$ ). Enzymes of peak V, which eluted at 0.12-0.20 $\mathrm{M}-\mathrm{KCl}$, showed appreciable casein-degrading activity in the presence of $3 \mathrm{~mm}$-ATP but not in its absence. Stimulation by ATP was 8-12-fold (Fig. 5a). Enzymes of peaks VI and VII showed activity against casein and insulin, respectively, although their separation with the DEAE-Sephacel column was incomplete.

When dialysed cell-free extracts prepared from cells grown at $13{ }^{\circ} \mathrm{C}$, or from cells grown at either $0{ }^{\circ} \mathrm{C}$ or $13^{\circ} \mathrm{C}$ and then exposed to temperature shifts, were applied to a DEAE-Sephacel column, the proteolytic enzymes showed qualitatively the same elution profile as that in Fig. 5.

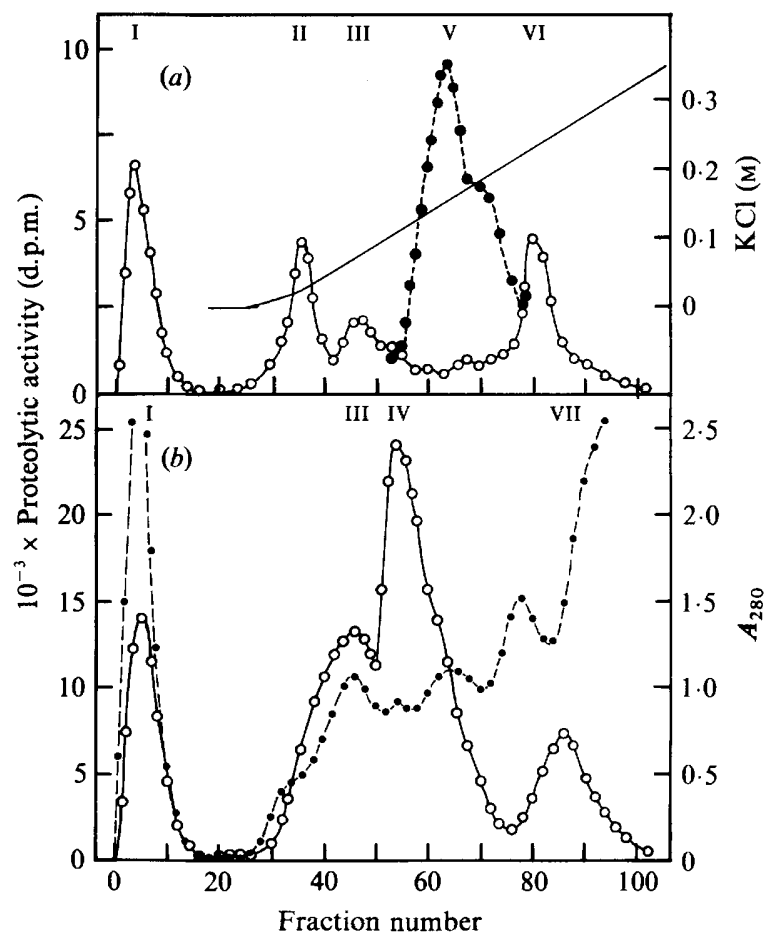

Fig. 5. DEAE-Sephacel chromatography of proteolytic enzymes from Vibrio sp. strain ANT-300. Dialysed cell-free extract of cells grown at $0{ }^{\circ} \mathrm{C}$ was passed through a DEAE-Sephacel column and the bound proteins were eluted as described in Methods. The seven activity peaks are designated I-VII, according to their order of elution from the column. (a) Casein-degrading activity in the absence $(O)$ or presence (e) of $3 \mathrm{mM}$-ATP was assayed at $20^{\circ} \mathrm{C}$ for $120 \mathrm{~min}$. — Gradient of $\mathrm{KCl}$ concentration. (b) Insulin-degrading activity in the absence of ATP was assayed at $20^{\circ} \mathrm{C}$ for $60 \mathrm{~min}(\mathrm{O}) . \bullet---\bullet, \mathrm{A}_{280}$ of eluted material.

Table 3. Effects of various protease inhibitors on the hydrolysis of casein by enzyme(s) of peak $V$

Reaction mixtures $(100 \mu \mathrm{l})$ containing $50 \mathrm{~mm}-\mathrm{Tris} / \mathrm{HCl}(\mathrm{pH} 8.0)$, $10 \mathrm{~mm}-\mathrm{MgCl}_{2}, 3 \mathrm{~mm}-\mathrm{ATP}, 20 \mu \mathrm{l}$ of enzyme solution, and the indicated inhibitors were incubated for $5 \mathrm{~min}$ at $20^{\circ} \mathrm{C}$ prior to the addition of $\left[{ }^{14} \mathrm{C}-\mathrm{Me}\right]$ casein $(10 \mu \mathrm{g})$. Enzyme solution was prepared from cells grown at $0{ }^{\circ} \mathrm{C}$. Incubations were done at $20^{\circ} \mathrm{C}$ for $60 \mathrm{~min}$. The relative activity is expressed as a percentage of the activity in the absence of inhibitors. The values given are means of four independent experiments.

\begin{tabular}{lcc}
\hline \hline \multicolumn{1}{c}{ Addition } & $\begin{array}{c}\text { Concn } \\
(\mathrm{mM})\end{array}$ & $\begin{array}{c}\text { Relative } \\
\text { activity } \\
(\%)\end{array}$ \\
\hline None & - & 100 \\
PMSF & 2 & 85 \\
& 5 & 66 \\
HMPS & 10 & 34 \\
$N$-Ethylmaleimide & 2 & 87 \\
& 5 & 74 \\
o-Phenanthroline & 5 & 84 \\
& 10 & 70 \\
& 1 & 84 \\
\hline \hline
\end{tabular}




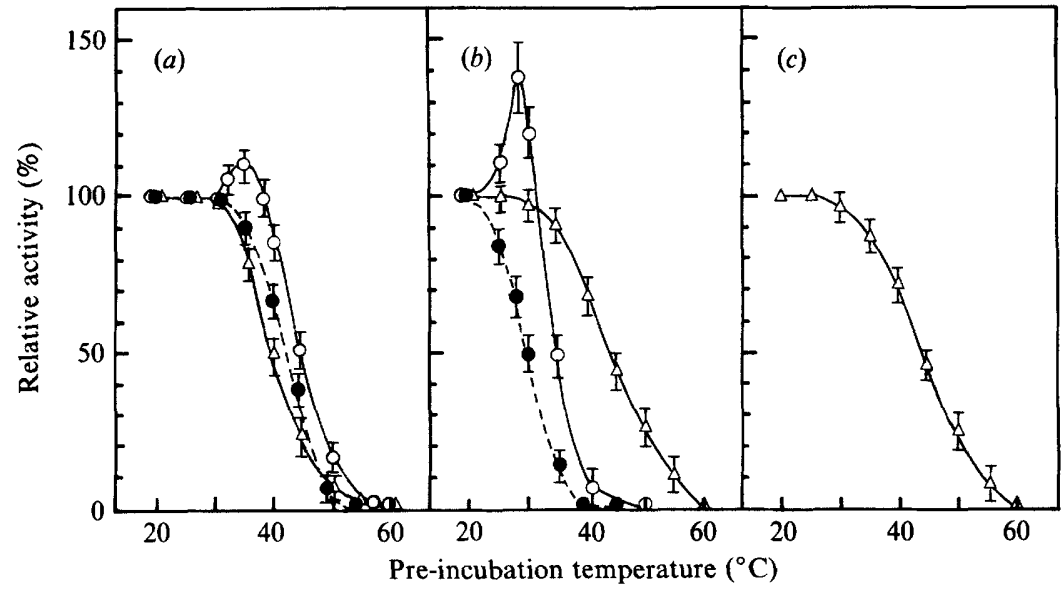

Fig. 6. Thermostability of the proteolytic enzymes in Vibrio sp. strain ANT-300. Dialysed cell-free extracts $(a)$, peak V $(b)$ and peak IV $(c)$ were pre-incubated for $30 \mathrm{~min}$ at the indicated temperatures and allowed to cool before the addition of substrate. The degradation of $\left[{ }^{14} \mathrm{C}\right.$-Me]casein in the absence $(O)$ or presence $(\bullet)$ of $3 \mathrm{mM}$-ATP and of $\left[{ }^{14} \mathrm{C}\right.$-Me $]$ insulin $(\triangle)$ at $20^{\circ} \mathrm{C}$ was measured. The results are expressed as percentages of the initial activity. The points and bars represent means from five experiments and ranges of results, respectively.

\section{Characterization of ATP-dependent protease(s)}

The casein-degrading activity of peak $\mathrm{V}$ was dependent on the presence of ATP and $\mathrm{Mg}^{2+}$ ions. Maximal stimulation of proteolytic activity was obtained at $3 \mathrm{mM}$ ATP. Other nucleoside triphosphates and ADP were less effective than ATP (data not shown). To characterize the enzyme(s) in peak $V$ further, several protease inhibitors were tested (Table 3). The enzyme(s) appeared to be a serine protease since it was strongly inhibited by $10 \mathrm{mM}$ PMSF, although total inhibition was not achieved. In addition, this enzyme appeared to require free thiol groups for function, as $N$-ethylmaleimide and HMPS were also inhibitory. The ATP-dependent hydrolysis of casein was also affected by $o$-phenanthroline, which chelates divalent cations.

\section{Thermostability of proteolytic enzymes}

Dialysed cell-free extracts, and peaks IV and V, were pre-incubated for $\mathbf{3 0} \mathrm{min}$ at various temperatures above $20^{\circ} \mathrm{C}$ and their ability to hydrolyse casein and insulin was then examined at $20^{\circ} \mathrm{C}$ in the absence or presence of 3 mM-ATP (Fig. 6). In the extracts of cells grown at $0{ }^{\circ} \mathrm{C}$, the hydrolysis of insulin and the ATP-dependent hydrolysis of casein were both decreased to some extent by pre-incubation at temperatures above $32^{\circ} \mathrm{C}$. The ATP-independent hydrolysis of casein was increased by pre-incubation at temperatures between 30 and $35^{\circ} \mathrm{C}$, but was decreased if the pre-incubation temperature was above $38^{\circ} \mathrm{C}$ (Fig. $6 a$ ). The enzymes in extracts prepared either from cells grown at $13^{\circ} \mathrm{C}$ or from cells exposed to temperature shifts had the same thermostability as the enzymes in extracts of cells grown at $0^{\circ} \mathrm{C}$ (data not shown).

The enzyme(s) responsible for ATP-dependent hydrolysis of casein in peak $V$ was inactivated to some extent by pre-incubation at $25^{\circ} \mathrm{C}$ and completely inactivated by pre-incubation at temperatures above $40^{\circ} \mathrm{C}$, whereas the activity of enzymes responsible for ATP-independent hydrolysis of casein was increased by pre-incubation at temperatures between 25 and $30^{\circ} \mathrm{C}$ (Fig. 6 b). After preincubation at temperatures above $30^{\circ} \mathrm{C}$, the activity decreased, and the enzyme was completely inactivated by $30 \mathrm{~min}$ pre-incubation at temperatures above $40^{\circ} \mathrm{C}$. The insulin-degrading activity in peak $\mathrm{V}$, which also contained some of the enzyme of peak IV, decreased slightly after pre-incubation at $30^{\circ} \mathrm{C}$ and all activity was lost after heating at $60^{\circ} \mathrm{C}$ for $30 \mathrm{~min}$ (Fig. $6 \mathrm{~b}$ ). The protease which hydrolysed insulin but not casein (peak IV) was inactivated by heating at temperatures above $30{ }^{\circ} \mathrm{C}$, and its heat-induced inactivation profile was the same as that of insulin-hydrolysing enzyme in peak $\mathrm{V}$ (Fig. $6 b, c$ ).

\section{Discussion}

In the psychrophilic bacterium Vibrio sp. strain ANT300, ATP-dependent proteolysis, measured in cell extracts, varied slightly with growth temperature. ATPindependent activity was not affected. ATP-dependent activity in the extracts of cells exposed to temperature shifts increased by about $36 \%$ and $17 \%$ as compared with the activity in extracts of cells grown solely at $0{ }^{\circ} \mathrm{C}$ and $13^{\circ} \mathrm{C}$, respectively (Tables 1 and 2). Similarly, ATPstimulated proteolysis in Arthrobacter globiformis $\mathrm{S}_{1} 55$ has been demonstrated to be increased by a shift from $10{ }^{\circ} \mathrm{C}$ to $32^{\circ} \mathrm{C}$ (Potier et al., 1990). The proteolytic enzymes detected in cells of Vibrio sp. strain ANT-300 grown at different temperatures and exposed to temperature shifts showed the same temperature dependency and heat lability (Figs 4 and $6 a$ ). These results suggest that the level of ATP-dependent protease(s), rather than the type of enzyme, may be regulated in response to environmental temperature. 
E. coli contains at least 15 different endoproteases, two of which are ATP-dependent serine proteases $\mathrm{La}$ and $\mathrm{Ti}$ (Clp) (Charette et al., 1981; Chung \& Goldberg, 1981; Hwang et al., 1987; Katayama et al., 1988; Miller, 1987). In $h t p R$ mutants the intracellular level of protease $\mathrm{La}$ and the cell's capacity to degrade abnormal proteins are reduced (Baker et al., 1984; Goff et al., 1984; Goff \& Goldberg, 1987).

An ATP-dependent proteolytic system resembling that in E. coli (Murakami et al., 1979) has been observed in unfractionated cell-free extracts of Vibrio sp. strain 14 (Car \& Woods, 1984). In the present study, we found that Vibrio sp. strain ANT-300 contained at least seven distinct proteases and that the casein-degrading activity of one of these was strongly dependent on the presence of ATP and $\mathrm{Mg}^{2+}$ ions (Fig. 5). The enzyme(s) with ATPdependent activity was sensitive to a serine protease inhibitor (PMSF) and thiol-group inhibitors (Table 3). Therefore, it seems likely that Vibrio sp. strain ANT-300 contains ATP-dependent serine protease(s), similar to those in E. coli. The ATP-dependent serine protease(s) might thus play an important role in the selective degradation of proteins in response to changes in temperature.

In the present study, the marked increase in the rate of degradation of proteins in vivo caused by a shift in temperature exceeded the increase in proteolytic activity detected in corresponding cell extracts (Table 2, Fig. 3). Moreover, the increase in the protein degradation rate in vivo caused by a shift-up in temperature was repressed by the addition of rifampicin (Fig. 2). These results suggest that the increased rate of protein degradation in vivo in cells exposed to temperature shifts may result not only from an increase in the level of protease(s) but also from increased synthesis of cellular proteins that are more susceptible to degradation.

The induction of the synthesis of proteins in response to temperature shifts has been reported in various coldadapted mico-organisms (Araki, 1991 $a, b$; Julseth \& Inniss, 1990; Maniak \& Nellen, 1988; McCallum et al., 1986, 1989; McCallum \& Inniss, 1990; Muller-Taubenberger et al., 1988). The cellular response to changes in temperature could be associated with an increase in the synthesis of short-lived proteins that are programmed to bring about the reorganization of metabolic networks. Moreover, the accumulation of susceptible proteins would be a direct result of changes in temperature, since such changes would lead to miscoding during protein synthesis and to conformational changes in proteins present before the changes in temperature.

The thermostability of ATP-dependent proteases in cold-adapted micro-organisms is of particular interest. The ATP-dependent serine protease in Vibrio sp. strain ANT-300 was much more heat-labile than those reported in E. coli (Goldberg et al., 1981). The ATP-dependent protease activity was decreased by pre-incubation at temperatures above $25^{\circ} \mathrm{C}$, whereas the ATP-independent activity was increased by heating at temperatures between 25 and $30^{\circ} \mathrm{C}$, and then decreased above $30^{\circ} \mathrm{C}$ (Fig. 6b). In crude extracts of Arthrobacter globiformis $\mathrm{S}_{1} 55$ casein degradation is similarly increased by heating at temperatures between 40 and $60^{\circ} \mathrm{C}$ (Potier et al., 1990). The degree of the heat-induced activation in $\boldsymbol{A}$. globiformis was much greater than that reported here. The physiological function of this apparently latent proteolytic activity, and the mechanisms by which the heating elicits activation, are still unknown.

\section{References}

Amelunxen, R. E. \& Murdoch, A. L. (1983). Microbial life at high temperatures: mechanisms and molecular aspects. In Microbial Life in Extreme Environments, pp. 217-270. Edited by D. J. Kushner. New York: Academic Press.

ARAKI, T. (1991a). The effects of temperature shifts on protein synthesis by the psychrophilic bacterium Vibrio sp. strain ANT-300. Journal of General Microbiology 137, 817-826.

ARAKI, T. $(1991 b)$. The changes in the rates of synthesis of individual proteins in a psychrophilic bacterium after a shift in temperature. Canadian Journal of Microbiology 37, 840-847.

Baker, T. A., Grossman, A. D. \& Gross, C. A. (1984). A gene regulating the heat shock response in Escherichia coli also affects proteolysis. Proceedings of the National Academy of Sciences of the United States of America 81, 6779-6783.

CAR, N. G. \& Woods, D. R. (1984). Protein degradation in extracts of exponential and stationary phase Vibrio cells. Journal of General Microbiology 130, 2775-2781.

Charette, M. F., Henderson, G. W. \& Markovitz, A. (1981). ATP hydrolysis-dependent protease activity of the lon (capR) protein in Escherichia coli K-12. Proceedings of the National Academy of Sciences of the United States of America 78, 4728-4732.

ChUNG, C. A. \& GoldberG, A. L. (1981). The product of the lon (capR) gene in Escherichia coli is the ATP-dependent protease, protease La. Proceedings of the National Academy of Sciences of the United States of America 78, 4931-4935.

Dottavio-Martin, D. \& RAvel, J. M. (1978). Radiolabeling of proteins by reductive alkylation with $\left[{ }^{14} \mathrm{C}\right]$ formaldehyde and sodium cyanoborohydride. Analytical Biochemistry 87, 562-565.

GofF, S. A. \& GoldBerg, A. L. (1987). An increased content of protease $\mathrm{La}$, the lon gene product, increases protein degradation and blocks growth in Escherichia coli. Journal of Biological Chemistry 262, 4508-4515.

Goff, S. A., Casson, L. P. \& Goldberg, A. L. (1984). Heat shock regulatory gene $h t p R$ influences rates of protein degradation and expression of the lon in Escherichia coli. Proceedings of the National Academy of Sciences of the United States of America 81, 6647-6651.

Goldberg, A. L., Swamy, K. H. S., Chung, C. H. \& Larimore, F. S. (1981). Proteases in Escherichia coli. Methods in Enzymology 80, 680702.

GoTTESMAN, S. (1987). Regulation by proteolysis. In Escherichia coli and Salmonella typhimurium: Cellular and Molecular Biology, pp. 13081312. Edited by F. C. Neidhardt and others. Washington, DC: American Society for Microbiology.

Hipkiss, A. R., Armstrong, D. W. \& Kushner, D. J. (1980). Protein turnover in a moderately halophilic bacterium. Canadian Journal of Microbiology 26, 196-203.

Hwang, B. J., Park, W. J., Chung, C. H. \& Goldberg, A. L. (1987) Escherichia coli contains a soluble ATP-dependent protease (Ti) distinct from protease La. Proceedings of the National Academy of Sciences of the United States of America 84, 5550-5554. 
JULSETH, C. R. \& INNISS, W. E. (1990). Induction of protein synthesis in response to cold shock in the psychrotrophic yeast Trichosporon pullulans. Canadian Journal of Microbiology 36, 519-524.

Katayama, Y., Gottesman, S., Pumphrey, J., Rudikoff, S., Clark, W. P. \& Maurizi, M. R. (1988). The two-component, ATPdependent Clp protease of Escherichia coli. Purification, cloning, and mutational analysis of the ATP-binding component. Journal of Biological Chemistry 263, 15226-15236.

Larrabee, K. L., Phillips, J. O., Williams, G. J. \& Larrabee, A. R. (1980). The relative rates of protein synthesis and degradation in a growing culture of Escherichia coli. Journal of Biological Chemistry 225, 4125-4130.

ManiaK, M. \& Nellen, W. (1988). A developmentally regulated membrane protein gene in Dictyostelium discoideum is also induced by heat shock and cold shock. Molecular and Cellular Biology 8, 153159.

McCallum, K. L. \& INNiss, W. E. (1990). Thermotolerance, cell filamentation, and induced protein synthesis in psychrophilic and psychrotrophic bacteria. Archives of Microbiology 153, 585-590.

McCallum, K. L., Heikkila, J. J. \& InNiss, W. E. (1986). Temperature-dependent pattern of heat shock protein synthesis in psychrophilic and psychrotrophic microorganisms. Canadian Journal of Microbiology 32, 516-521.

McCallum, K. L., Sutler, B. J. \& InNiss, W. E. (1989). Stress of heat shock protein synthesis and cellular filamentation in psychrophilic and psychrotrophic microorganisms. Archives of Microbiology 152, 148-153.

MiLLER, C. G. (1987). Protein degradation and proteolytic modification. In Escherichia coli and Salmonella typhimurium: Cellular and Molecular Biology, pp. 680-691. Edited by F. C. Neidhardt and others. Washington, DC: American Society for Microbiology.
Mosteller, R. D., Goldstein, R. V. \& Nishimoto, K. R. (1980). Metabolism of individual proteins in exponentially growing Escherichia coli. Journal of Biological Chemistry 255, 2524-2532.

Muller-Taubenberger, A., HagmanN, J., Nogel, A. \& Gerisch, G. (1988). Ubiquitin gene expression in Dictyostelium is induced by heat and cold shock, cadmium, and inhibitors of protein synthesis. Journal of Cell Science 90, 51-58.

Murakami, K., Voellmy, R. \& Goldberg, A. L. (1979). Protein degradation is stimulated by ATP in extracts of Escherichia coli. Journal of Biological Chemistry 254, 8194-8200.

PINE, M. J. (1972). Turnover of intracellular proteins. Annual Review of Microbiology 26, 103-126.

Potier, P., HiPkiss, A. R. \& KuShNeR, D. J. (1985). Protein turnover in a psychrotrophic bacterium. Archives of Microbiology 142, 28-33.

Potier, P., Drevet, P., Gounot, A. M. \& HiPkiss, A. R. (1987a). Protein turnover in a psychrotrophic bacterium: proteolytic activity in extracts of cells grown at different temperatures. FEMS Microbiology Letters 44, 267-271.

Potier, P., Drevet, P., Gounot, A. M. \& HiPkiss, A. R. (1987b). ATP-dependent and -independent protein degradation in extracts of the psychrotrophic bacterium Arthrobacter sp. $\mathrm{S}_{1} 55$. Journal of General Microbiology 133, 2797-2806.

Potier, P., Drevet, P., Gounot, A. M. \& Hipkiss, A. R. (1990). Temperature-dependent changes in proteolytic activities and protein composition in the psychrotrophic bacterium Arthrobacter globiformis $\mathrm{S}_{1}$ 55. Journal of General Microbiology 136, 283-291.

St John, A. C. \& Goldberg, A. L. (1978). Effects of reduced energy production on protein degradation, guanosine tetraphosphate, and RNA synthesis in Escherichia coli. Journal of Biological Chemistry 253, 2705-2711. 